\title{
O poeta insone
}

Fabio Cesar Alves ${ }^{a}$

\section{Resumo}

O objetivo do artigo é o de compreender, por meio da análise do poema "Campo, chinês e sono", de A rosa do povo (1945), a maneira pela qual Carlos Drummond de Andrade responde, crítica e criativamente, às composições cabralinas de Pedra do sono, pautadas pela tentativa de dessubjetivação e esquecimento de si. Para esse fim, o texto se vale da correspondência entre os autores e de formulações teóricas do próprio Cabral. A resposta poética e política de Drummond em "Campo, chinês e sono", no qual se pressente utopicamente a construção de uma sociedade justa e emancipada, permite repensar também a suposta intransitividade de alguns dos poemas herméticos de A rosa do povo.

Palavras-chave: Carlos Drummond de Andrade; João Cabral de Melo Neto; lírica e sociedade; lírica moderna; Comunismo.

a Professor de Literatura Brasileira na Universidade de São Paulo; E-mail: fabiocesar.alves@terra.com.br. 
Eu preparo uma canção

que faça acordar os homens

e adormecer as crianças.

(Carlos Drummond de Andrade, "Canção amiga")

\section{Aniquilação e adormecimento}

Entre as muitas veredas abertas pela leitura que Antonio Candido fez da poesia de Drummond, uma delas leva à presença determinante, na obra do poeta mineiro, de uma subjetividade tirânica que, traduzida em humor nos primeiros livros, chegaria ao ápice da autodestrutividade em $A$ rosa do povo (1945). Segundo o crítico, a "inquietude com o eu", traço elementar da obra de Drummond, assumiria formas de automutilação na obra de 1945 (CANDIDO, 1970, p. 100-101). De modo geral, Candido destaca nos poemas um constante desejo de transformação do mundo, correspondente à ânsia de extinção do próprio ser - perspectiva de redenção simultânea que implicaria, por parte da subjetividade, a percepção da própria impotência e a necessidade de liquidação do "eu torto" como condição de uma nova ordem, prefigurada, à época, pelas iminentes derrotas do nazifascismo e da ditadura varguista. Tal postura explicaria, em grande medida, a profusão de imagens autodestrutivas do livro, uma vez que o eu poético almeja eliminar, em si mesmo, o burguês a quem dirige o seu ódio, em um gesto que atualiza a figura baudelairiana do "carrasco de si mesmo". Como consequência, no interior de A rosa do povo convivem muitas variantes do processo de negação do ser e do dilaceramento autocrítico, tais como os "estados angustiosos do sonho, da sufocação, do sepultamento e do sentimento de inumação em vida" (CANDIDO, 1970, p. 100), e também o espectro de imagens derivadas do adormecimento e dos estágios de sonolência, presentes já no verso de abertura do volume: "Não rimarei a palavra sono/com a incorrespondente palavra outono" "Consideração do poema" (ANDRADE, 2012b, p. 9). Em "Vida menor", o eu-lírico procura a "vida mínima, essencial"; um "sono" que corresponda ao não-tempo de uma outra humanidade (ANDRADE, 2012b, p. 49). Algo dessa ordem também reaparece no encerramento $\mathrm{d}^{\prime} A$ rosa, por meio do "Canto ao homem do povo Charles Chaplin", no qual a "bengala mágica" de Carlito reconduz os homens ao "país 
1 Além dos poemas mencionados, diversas composições de A Rosa do povo fazem menção ao adormecimento e aos estados letárgicos, como "Procura da poesia", "Nosso tempo", "Passagem da noite", "Nos áureos tempos", "Fragilidade", "Vida Menor", "Morte do leiteiro", "Consolo na praia", "Rua da madrugada", "Versos à boca da noite", "América". secreto onde dormem meninos" (ANDRADE, 2012b, p. 159), figuração do ideal compartilhado que permite vislumbrar um reino secreto de barreiras e individualidades desfeitas em favor de uma vida solidária, coesa e límpida, sintetizadas pela personagem mundialmente famosa.

É possível perceber, portanto, que na obra de 1945 existem inúmeras alusões e referências diretas ao estado do sono, concebido como estratégia de aniquilamento da subjetividade pequeno-burguesa e como figuração da própria utopia, processos muitas vezes combinados ${ }^{1}$. De modo geral, a profusão de imagens ligadas ao adormecimento e aos estados letárgicos - cuja variante é própria ideia de morte, como a reiterar, em chave histórico-poética, a mítica relação fraterna entre Hypnos e Thanatos - pode ser entendida como um dos eixos sobre o qual se constitui a arquitetura rigorosa d'A rosa do povo.

\section{Procura da pureza}

Não parece casual que o sono e o aniquilamento do sujeito como matéria poética tenham inquietado, também nos primeiros anos da década de 1940, um dos principais interlocutores de Drummond, o poeta João Cabral de Melo Neto. A obra de estreia de Cabral, Pedra do sono (1942), foi compreendida por boa parte da crítica como um conjunto de poemas cuja compleição fundamentalmente imagética remeteria à ilogicidade surrealista, mantida sob controle, todavia, por uma consciência poética que enfatizaria o gesto raciocinante. Como formula João Alexandre Barbosa, os primeiros vínculos de Cabral com o surrealismo implicavam a presença do onírico temático e as balizas de um construtivismo abstrato, o qual distanciava o seu estilo da escrita automática dos surrealistas avant la lettre. Por outra, as imagens inusitadas surgiam, na Pedra do sono, em um arquitetado espaço plástico no qual seria possível, como nas telas de Joan Miró e Paul Klee, a convivência do ingênuo com a mais rigorosa técnica de abstração (BARBOSA, 1975, p. 23-24). De modo que os objetos, neste livro, seriam como projeções da vida mental do sujeito, testemunhos de um "eu múltiplo" que parecia diluído no mundo das coisas, mas que ainda estaria presente. (PEIXOTO, 1983, p. 21)

Antonio Candido, ainda em 1943, reconhecia esse rigor construtivista, o qual levaria o próprio Cabral a definir a Pedra do 
sono como exemplo de um "surrealismo fingido" (FREIXEIRO, 1971, p. 182), mas não deixou de atribuir o hermetismo das composições (o "mundo fechado de uma poesia que tende a bastar-se a si mesma") (CANDIDO, 2002, p.141) à imaturidade do poeta, apostando que o autor estreante haveria "de perceber que lhe será preciso o trabalho de olhar um pouco à roda de si, para elevar a pureza da sua emoção a valor corrente entre os homens"(CANDIDO, 2002, p. 141). Menos do que a maturidade do primeiro Cabral, estava em questão para Candido o poder de comunicação da obra poética, sua razão de ser em tempos de guerra total e de ditadura estadonovista. Uma transitividade, enfim, ausente da Pedra do sono, o que levava o crítico a concluir que toda pureza implicava necessariamente um aspecto de "desumanização".

Muitas das composições do primeiro livro de Cabral desenvolvem poeticamente aquilo que o próprio autor teorizara em 1941, no Congresso de Poesia do Recife. Em "Considerações sobre o poeta dormindo", ele defendia a tese do "sono" como um estágio de predisposição à poesia, porque caracterizado por uma situação marginal do eu, na qual ele poderia contemplar-se como objeto (MELO NETO, 1994, p. 686-687). Esse eu marginal daria o tom dos poemas da Pedra do sono, os quais se valem de justaposições inesperadas e de imagens insólitas como objetos que, vistos com distanciamento, refratam, no entanto, o mundo psíquico do eu-lírico. Para John Gledson, o "tom indeterminado" da obra não excluiria nem a objetividade, que Cabral já começava a perseguir e que o consagraria a partir de $O$ engenheiro, nem um subjetivismo tão autodestrutivo quanto o de Drummond e herdado dos modernistas, uma vez que os objetos parecem se situar ao mesmo tempo dentro $e$ fora da mente do poeta (GLEDSON, 2003, p. 178-179). Assim, em "O poema e a água", as "vozes líquidas" que "convidam ao crime" (MELO NETO, 1994, p. 95) repetem-se na memória de uma subjetividade apenas na aparência ausente. No poema "Marinha", as mulheres em cujos sonhos "cavalos passam correndo" (MELO NETO, 1994, p. 48) dão lugar ao céu imaginado pelo eu-lírico, como imagens insólitas que se mostram como projeções dele. Em "Homem falando no escuro", a despeito da impessoalidade do título, é o próprio sujeito lírico quem se sente "adormecer/ e despertar para as paisagens mais quotidianas" (MELO NETO, 1994, p. 49). 
Como se pode notar, a tentativa de aniquilação por meio do sono é uma estratégia compartilhada tanto pelo Cabral de Pedra do sono quanto por Drummond n'A rosa do povo. Porém, se para Cabral a recorrência ao sono expressa a tentativa de construir poeticamente uma "zona neutra", determinada por um sujeito pensante e ainda assim livre dele (GLEDSON, 2003, p. 194) - um prenúncio da discussão sobre o caráter objetivo da obra de arte, que se tornaria verdadeira obsessão para o poeta pernambucano -, para Drummond, como veremos, o sono seria um dos recursos que paradoxalmente incitariam a ação do sujeito e garantiriam o florescimento, ainda que apenas intuído, de uma nova ordem, na qual a individualidade pequeno-burguesa finalmente poderia deixar de existir.

\section{O sono vigilante}

O diálogo poético travado entre Drummond e Cabral em torno do sono ganha força se se levar em conta a discussão epistolar travada por ambos, e que teve início dos anos 1940 (SUSSEKIND, 2001, p. 7-8). Em uma das cartas, como comentário à leitura de Sentimento do mundo, Cabral confessa a Drummond querer chegar, um dia, àquela linguagem que compensaria a existência de "sociólogos, estatísticas e ditadores" (SUSSEKIND, 2001, p. 165). Já a resposta de Drummond ao exemplar de Pedra do sono não poderia ser mais precisa: os poemas cabralinos teriam muito de hermetismo para o leitor comum, ao partirem de "associações de coisas e estados de espírito que excederiam a lógica rotineira" (SUSSEKIND, 2001, p. 174). A certa altura, as reservas, antes apenas esboçadas, ficariam mais nítidas a ponto de autorizarem o poeta mineiro a aconselhá-lo:

Já meditou na fascinante experiência que seria fazer livros de custo ínfimo, com páginas sugestivas, levando a poesia moderna aos operários, aos pequenos funcionários públicos, a toda essa gente atualmente condenada a absorver uma literatura de quarta classe porque se convencionou reservar certos gêneros e tendências para o pessoal dos salões e das universidades? [...] Eu acredito que v. está procurando caminho, e que há muita coisa a fazer antes de chegarmos a uma poesia integrada ao nosso tempo, que o exprima limpidamente e que ao mesmo tempo o supere. (SUSSEKIND, 2001, p. 174-175) 
Como se pode notar, as ressalvas de Drummond à Pedra do sono recaem sobre a necessidade, no contexto histórico dos anos 1940, de uma obra "integrada ao tempo", que deve comunicar a sua época e comunicá-la ao leitor, e que alcançasse também as classes subalternas, preocupação esboçada por Drummond desde Sentimento do mundo. Em suma: o caráter efetivamente político da poesia é que deveria guiar a obra de Cabral. Se, na década seguinte, a transformação da poética cabralina em uma obra enfaticamente transitiva se deu, as discussões iniciais entre o jovem poeta pernambucano e um de seus principais interlocutores produzem uma série de réplicas e tréplicas artísticas do maior interesse. Nesse sentido, tanto pelo que representa para a fatura de $A$ rosa do povo quanto por se tratar de uma resposta explícita ao primeiro Cabral é que ganha relevância o enigmático poema transcrito a seguir:

\section{Campo, chinês e sono}

A João Cabral de Melo Neto

10 chinês deitado

2 no campo. O campo é azul,

3 roxo também. O campo,

4 o mundo e todas as coisas

5 têm o ar de um chinês

6 deitado e que dorme.

7 Como saber se está sonhando?

8 O sono é perfeito. Formigas

9 crescem, estrelas latejam,

10 peixes são fluidos.

$11 \mathrm{E}$ árvores dizem qualquer coisa

12 que não entendes. Há um chinês

13 dormindo no campo. Há um campo

14 cheio de sono e antigas confidências.

15 Debruça-te no ouvido, ouve o murmúrio

16 do sono em marcha. Ouve a terra, as nuvens.

17 O campo está dormindo e forma um chinês

18 de suave rosto inclinado

19 no vão do tempo. (ANDRADE, 2012b, p. 50) 
${ }^{2}$ Nesse mesmo número da Revista Esfera, muitos textos aludem ao "mundo futuro", livre do fascismo e da miséria. É o caso de "Quero ajudar", poema de Maura de Sena Pereira ('Quero ajudar a construir o mundo futuro/e colocar a minha pedra no lugar exato e na hora certa"); de "Pedro Boloto", de Murilo Miranda, dedicado a Drummonde que trata de Stalingrado ("Quando o tanque/ Em minha direção/ Deslizou pesadamente, Diz o soldado/Pedro Boloto,/Pensei que era/O fim do mundo)"; e do poema "Ghetto", de Affonso Frederico Schmidt, sobre os judeus acossados pela guerra. Há ainda artigos como "A arte e sua irradiação social", de Quirino Campofiorito, responsável por ilustrar o poema de Drummond. A vitória contra o nazifascismo com vistas a um horizonte socialista era, portanto, a pedra de toque da publicação.

${ }^{3} \mathrm{O}$ aspecto pictórico do poema, com soluções i n t e r p retativas bastante diversas, foi apontado por Ana Maria Paulino, que relaciona a composição drummondiana aos quadros do pintor renascentista Giuseppe Arcimboldo ("Um pouco sobre 'Campo, chinês e sono". Revista do Instituto de Estudos Brasileiros, 29:7-13, 1988, p. 7-13).
Publicado pela primeira vez na Esfera: revista de letras, artes e ciências em março de 1944, periódico de orientação comunista que contava, entre seus redatores, com Jorge Amado, Eneida de Moraes e Graciliano Ramos (o que denota a inclinação momentânea do poeta pela esquerda partidária, que culminaria no cargo de diretor da Tribuna popular, logo abandonado), o poema é o primeiro que Drummond dedica, explicitamente, a Cabral ${ }^{2}$.

Provocadoramente, há muito do poeta pernambucano no "Campo, chinês e sono", a começar pelo título, uma vez que a disposição dos substantivos em série parece reproduzir a impessoalidade e o acúmulo de imagens à primeira vista sem nexo, recursos recorrentes em Cabral. Tal provocação é reiterada pelo caráter fanopaico da composição, que explora a imagem do chinês deitado em suas potencialidades expressivas. A construção de um campo "azul e roxo" (versos 2 e 3) leva à precedência do plástico sobre o discursivo, traço central da primeira poesia cabralina (Cf. CAMPOS, 2006, p. 80): um cenário desrealizado, mas rigorosamente construído e dinâmico, sujeito a incessantes mutações ${ }^{3}$. O procedimento empregado por Drummond pode ser melhor compreendido à luz da leitura que o poeta pernambucano fez das obras do pintor catalão Joan Miró, artista cuja importância teria sido a de romper com o perspectivismo renascentista, devolvendo à superfície da tela a função de ser um "receptáculo do dinâmico" (MELO NETO, 1994, p. 697). As pinturas de Miró representariam uma luta "contra o estático da própria cor e contra o estático próprio da contemplação de figuras conhecidas e aprendidas de memória" (MELO NETO, 1994, p. 704-705). À primeira vista, há algo em direção a esse dinamismo aperspectívico no campo drummondiano, que "é azul, roxo também", e nas transformações por que passam as figuras do poema: se "o mundo e todas as coisas" parecem o chinês (versos 3 e 4), ao final este é formado pelo campo (versos 17 e 18). De tal modo que o leitor é incitado não a contemplar a figura por meio de um ponto de fuga estático, mas a acompanhar as metamorfoses da imagem e da cor que parecem se desenrolar diante de seus olhos. Como no Cézanne analisado por Merleau Ponty, o poema dá a impressão de constituir uma paisagem como "organismo nascente", um objeto em via de aglomerar-se ao tempo do olhar, 
uma vez que as linhas das imagens se insinuam à medida que são percebidas. (MERLEAU PONTY, 2004, p. 129)

Do ponto de vista da estrutura, os seis primeiros versos, que descrevem o chinês dormindo, reforçam, por meio dos verbos de ligação, o quadro sereno e harmônico que a voz poética procura descrever, em oposição às formas imperativas que demandam ação, e que por isso destoam do conjunto, dos versos 15 e 16. A imagem íntegra do chinês nessa abertura é descrita, no entanto, por meio de uma sucessão de enjambements que, somados às cesuras, se contrapõem à integridade da imagem descrita. O poema então apresenta duas tensões fundamentais: 1) a oposição entre "ação" e "contemplação" expressa pelos verbos; e 2) o contraste entre a imagem serena do chinês no campo e os versos entrecortados (e cesurados) que revelam o lugar distinto de onde fala o eu-lírico.

Portanto, o poema explora uma unidade imagética (o chinês dormindo) que, aos poucos, se desdobra e se transforma dinamicamente, e o sujeito lírico parece encontrar-se fora do quadro, tal qual os "olhos telescópicos que espiam a rua" (MELO NETO, 1994, p. 43) do primeiro Cabral. Ainda por meio desse distanciamento apenas inicial, a voz poética é capaz de constatar, nos versos 3 a 6, que tudo "tem o ar de um chinês/ deitado e que dorme", sem que haja uma completa identificação entre essas instâncias, o que ocorrerá apenas nos últimos versos.

Aos poucos, o eu-lírico drummondiano torna-se mais próximo da cena, a ponto de (se) questionar, sobre a figura que dorme: "Como saber se está sonhando"? A partir do sétimo verso a voz poética, abandonando a ideia de "sonho", passa a expressar o conteúdo do "sono" do chinês, de modo que, agora, uma metamorfose estrutural se opera: a do sujeito lírico que, abandonando sua posição aparentemente estável, procura explicar o quadro que observa. Como nos poemas de Pedra do sono, a aparente objetividade da cena é tensionada por uma presença subjetiva.

O "sono perfeito", descrito pela voz poética como se fosse o chinês tornado objeto de si, remeteria a um mundo desbloqueado, no qual cada ser poderia se desenvolver em plena potência - um universo de consonância que englobaria a terra (as formigas), as águas (os peixes) e o céu (as estrelas), mas do qual os homens estariam, ironicamente, excluídos. Daí a razão do "mundo e todas as coisas" terem ar de chinês: 
trata-se de um ideal utópico ainda não alcançado, cujos rastros, entretanto, seriam perceptíveis por toda parte. Assim como o elefante drummondiano, que sai em busca de "episódios não contados em livro", dos quais "apenas o vento/as folhas, a formiga/reconhecem o talhe", há algo na natureza alheio à impureza dos homens e por isso mesmo desejado, de que nem mesmo o chinês adormecido da abertura do poema parece, ainda, desfrutar, dada a situação de deslocamento e anulação de si impostas pelo sono.

Na sequência, os versos "e árvores dizem qualquer coisa//que não entendes" mostram também um "tu" fora desse domínio natural, e a interpelação à segunda pessoa pode se referir tanto ao eu-lírico desdobrado quanto ao próprio Cabral, a quem o poema é dedicado. O tema da disjunção entre o homem e a natureza, que ecoa o mar baudelairiano no qual somente o "homem liberto" poderia se ver inteiramente espelhado (BAUDELAIRE, 1985, p. 139), é formulada por Drummond de modo exemplar na crônica "A árvore e o homem":

Fiéis a si mesmas, decididas a guardar um silêncio que não está à mercê dos botânicos, procuram as árvores ignorar tudo de uma composição social que talvez se lhes afigure monstruosamente indiscreta, fundada como está na linguagem articulada, no jogo de transmissão do mais íntimo para o mais coletivo. [...] Realmente, é a sublime indiferença das árvores com relação ao pintor, escritor ou turista, que lhes confere essa dignidade vegetal a que inutilmente aspiramos, confundindo-a com placidez. [...] Amo vê-las em grupo ou isoladas [...] e até mesmo esparsas entre esses outros monumentos, os mais frágeis de todos, de nervos e vasos sanguíneos, que chamamos de homens, e tampouco sabem integrar-se no conjunto natural onde folhas, raízes, insetos e ventos se organizam sem política. (ANDRADE, 1975, p. 9)

Para o cronista, as árvores, assim como todos os elementos do conjunto natural, prescindem de qualquer tipo de organização social ou política, e também não se valem da linguagem articulada, entendida como o fundamento da vida social e artística. Portanto, à dignidade vegetal opõe-se a necessidade de comunicação, postergando para uma realidade futura a possiblidade de os homens, tais como as árvores, se "organizarem sem política". Tais concepções expressas na crônica auxiliam a compreensão da imagem do chinês e do campo nos versos 12,13 e 14 ("há um chinês dormindo no campo//há um campo cheio de sono e antigas confidências"), que não é idêntica à da abertura: 
há algo da ordem da temporalidade e da comunicação nessa segunda aparição, dimensões necessárias que se somam ao sono do chinês. $\mathrm{O}$ eu poético, encenando a sua entrada nesse universo onírico, atenta então para o contato que a figura do chinês estabelece com o espaço, com o tempo e com o ato de comunicar.

A referida menção ao tempo e à comunicação explica o apelo direto ao "tu" por meio de verbos imperativos que demandam ação ("Debruça-te no ouvido, ouve o murmúrio/do sono em marcha. Ouve a terra, as nuvens"), interpelação toda em metros jâmbicos, marcando em compassos mais duros o ritmo do próprio "sono em marcha”, que tem de necessariamente ser apreendido. É como se, por meio da partilha da realidade entre o eu-lírico e o interpelado ("comunicar", que remete a communis, tem o sentido de "partilhar") (HOUAISS, 2001, p.782), a integração definitiva com o conjunto natural fosse possível somente depois que o interlocutor se auscultasse e mergulhasse em seu tempo (um processo inverso, portanto, ao distanciamento esboçado pela Pedra do sono), anunciando um novo processo de metamorfose cujo resultado será a conjunção campo/ chinês do final do poema. Como a referência ao "tu" tanto pode ser dirigida a João Cabral quanto ao próprio eu-lírico, as necessidades de ouvir a si e ao mundo dizem muito das particularidades dessa voz e do que ela considera fundamental para a chegada do sono. Especialmente porque um gesto similar de autopercepção aparece formulado na crônica "Vila de utopia", em que Drummond revela o quanto Itabira, cidade cujo "destino mineral" a prendia ao "dorso fatigado da montanha", concederia a seus herdeiros certo modo de ver. Este passaria, necessariamente, pela imersão na própria interioridade: “em vão meus olhos perseguem a paisagem fluvial, a paisagem marítima: eu também sou filho da mineração, e tenho os olhos vacilantes quando saio da galeria escura para o dia claro". (ANDRADE, 2011, p. 127)

Como o universo mineiro, segundo o cronista, inclina-se para a subjetividade, a necessidade de contato com a realidade exterior implica um esforço quase artificial para o itabirano; no entanto, a partir da automediação é que ele se torna mais preparado a ver o mundo. Algo desse movimento se revela no poema, uma vez que o sono, após a interpelação do eu-lírico, resulta da relação do sujeito para consigo e com o entorno- um esforço que deve ser feito. A imposição dá a medida do potencial autocrítico do chamado (isto é, o quanto o sujeito lírico se sabe distante da práxis propriamente dita), e também revela como a dimensão pessoal da poesia drummondiana, trespassada pela devida mediação mineira, é acionada pela hora 
política do presente, no entrecruzamento de questões particulares e gerais que se retroalimentam no livro de 1945. Fundamental é que a aniquilação por meio do sono surge não como situação prévia tal qual na Pedra do sono, mas como consequência da capacidade do indivíduo de, ancorando-se na realidade, explicar-se historicamente - capacidade que é parte da condição do homem moderno e, em particular, um traço fundamental da lírica do poeta mineiro.

Ainda neste segmento, a expressão "murmúrio do sono em marcha" (verso 16) pode ser entendida tanto como uma personificação do sono que chega quanto um estágio de transformação radical trazido pela marcha, uma vez que o "sono" parece brotar do próprio ato de marchar. Assim como o poema, em termos estruturais, opera com a aparente estaticidade do chinês versus o movimento ativo de aproximação e de comunicação do eu-lírico, o "sono em marcha" sintetiza os princípios de ação e de aniquilação que justificam o apelo da voz poética ao tu.

A menção à "marcha" como metáfora do lançar-se no mundo é corrente na economia de $A$ rosa do povo: a caminhada por amplos espaços (ruas, cidades e continentes), configurando uma geografia de cunho político-ideológico, contrapõe-se à clausura do sujeito lírico que, nas obras anteriores, via o mundo por meio de molduras (CAMILO, 2014, p. 57-58). Neste caso específico, porém, a marcha combinada à figura do chinês revela também o quanto Drummond estava atento ao curso da história contemporânea, ao aludir a um episódio central da China comunista: a Grande Marcha (1934-1935). Nesse período, o Exército Vermelho, impelido ao movimento tático de retirada depois do massacre promovido pelas forças imperialistas, percorreu mais de dez mil quilômetros do território chinês e obteve uma estratégica vitória quando chegou ao norte do país, reconhecendo o movimento camponês como uma força social decisiva e incitando os trabalhadores rurais à formação de milícias contra o latifúndio. A "semeadeira para a revolução" estava lançada, afirmava Mao TséTung, alçado então à condição de líder. (SPENCE, 1995, p. 389-395)

A referência à China como berço de uma nova revolução não surpreende, posto que o país fazia parte do imaginário da intelectualidade de esquerda, militante ou não, pelo menos desde os anos 1930: a guerra civil contra os imperialistas que resultou no massacre de Xangai em 1927 fora tratada, entre outros escritores, por André Malraux, no romance A condição humana (1933) e por Brecht, na peça didática "A decisão" (1930). Em ambas as obras, o retrato das condições políticas da China vinha acompanhado de crítica às 
${ }^{4}$ Drummond tratara do mesmo episódio em "Canção de berço", de Sentimento do mundo, no qual aludia aos "quinhentos mil chineses mortos" (Op. Cit. São Paulo: Companhia das Letras, 2012, p. 25) e o Murilo Mendes das Metamorfoses, no poema "Armilavda", pontuava que "Na China da surpresa e da metamorfose/Morrem crianças e velhos metralhados" (Op. Cit. São Paulo: Cosac Naify, 2015, p.41).

${ }^{5}$ Ver, a respeito das discordâncias de Drummond com as orientações e a cúpula do PCB, O observador no escritório (Rio de Janeiro: Record, 1985), em especial as entradas de abril e agosto de 1945.

6 "Campo, chinês e sono" faz lembrar o poema "Le dormeur du val", de Arthur Rimbaud (1870), que trata da Guerra Franco-Prussiana. A voz poética rimbaudiana descreve um jovem adormecido no campo, deitado sobre "frescas águas azuis" e um "leito verde onde chove luz". Aproximando-se, o sujeito lírico revela tratar-se de um soldado morto: "E já não sente o odor das flores, o macio/ da relva. Adormecido, a mão sobre o peito,/Tem dois furos vermelhos do lado direito". ("O adormecido do vale". Tradução de Ferreira Gullar. In Autobiografia poética e outros textos. São Paulo: Autêntica, 2015). O movimento a proximativo d a subjetividade em relação ao quadro descrito e a contaminação do cenário idílico pelas imposições históricas do presente parecem, ainda que em contextos diversos, comuns às composições de ambos os poetas. diretrizes soviéticas, seja por meio dos guerrilheiros que discordavam da retirada estratégica proposta por Stalin, seja pela execução do camarada que se recusara a negociar com os comerciantes de arroz ${ }^{4}$.

No poema de Drummond, além da aposta em um socialismo que não passaria necessariamente pela via soviética, o que evidencia um engajamento livre da bitola stalinista e muito atento às diversas conjunturas políticas, a referência ao campo, por si só, aponta em contexto brasileiro para um universo de trabalho preterido até então pelos comunistas, inteiramente concentrados nos grandes centros urbanos e industriais. Em suma, a presença do campo e do chinês dão a medida, no poema, dos compromissos de Drummond com a esquerda, mas também da sua relação heterodoxa com as diretrizes partidárias, um embate que chegaria ao ápice em $1945^{5}$. Daí que a poetização do sono, em "Campo, chinês e sono", por estar imbricada à ideia da marcha, vindo necessariamente com ela, não exclui o processo histórico em suas versões internacional e local - antes o reforça, como elemento prévio e fundamental do ato de adormecer ${ }^{6}$.

Equilibrando-se na ambivalência do destinatário (o tu que é o eu desdobrado e, ao mesmo tempo, o poeta João Cabral), o poema de Drummond se constrói então como uma carta de intenções afinada com a lírica participante de $A$ rosa do povo e também como uma resposta poético-crítica ao primeiro Cabral, pois subverte a definição do sono como uma imediata e direta "incursão periódica no eterno" (MELO NETO, 1994, p. 688). O sono, em sua dimensão relacional, passa a ser consequência da relação do sujeito com o mundo, do chinês com o campo, do "eu" com o "tu", e não um "equilíbrio contra o mundo" ou "contra o tempo" como formulara Cabral (MELO NETO, 1994, p. 688). O mesmo poema enfrenta a indeterminação entre a presença e a ausência subjetivas, marcante no livro de estreia do escritor pernambucano, já que o movimento do eu-lírico, configurando uma subjetividade que se destaca de um quadro aparentemente impessoal e se dirige a outrem, opõe-se a qualquer minimização ou apagamento imediato de si. Ao contrário do Mallarmé citado na epígrafe da Pedra do sono ("Solitude, récif, étoile"), criador de uma poesia obscura e impessoal à sombra das derrotas de 1848, Drummond, cuja relação com o poeta francês é tensa e por vezes irônica n' A rosa do povo (Cf. GLEDSON, 2003, 47), parece alertar Cabral, em "Campo, chinês e sono" (uma espécie de eco irônico de "Solitude, récif, étoile") sobre os perigos de uma intransitividade e de uma dessubjetivação não autorizadas pela hora histórica, muito embora (e nisto consiste a força do engajamento 
drummondiano) a ênfase na comunicação, como se verá, não garanta por si uma perspectiva redentora.

A contraposição à atemporalidade e ao "eu deslocado" do primeiro Cabral justificam, em grande parte, o insuspeitado fio narrativo (o chinês dorme/o sono do chinês é descrito/o tu é interpelado e convocado a agir/o campo, então, forma o chinês) entrevisto no desenvolvimento dos versos, em uma peça que parecia alheia a qualquer causalidade. Assim, a própria estrutura silogística da composição incorpora deliberadamente a dimensão do tempo, da história e dos homens em sociedade. Na conclusão do poema, o campo, adormecido, forma efetivamente a figura oriental ("O campo está dormindo e forma um chinês/de suave rosto inclinado/no vão do tempo"), como se o processo decisivo pudesse se completar somente após o chamado ao outro (é porque se ouve a marcha que se chega mais perto do chinês formado pelo campo). Portanto, Drummond retifica em "Campo, chinês e sono" a ânsia de dessubjetivação de Pedra do sono, uma vez que a aniquilação do eu decorre da tarefa precípua de enfrentar-se e enfrentar a realidade objetiva, para então se abrir a possiblidade de uma ordem que prescinda da individuação.

No entanto, se há nesses últimos versos o pressentimento da construção de um mundo novo, existe também, pela interpelação ao tu que não vem acompanhada de resposta, o vislumbre de um porvir que permanece em latência, o que permite ao poeta adotar um posicionamento cauteloso quanto à concretização da utopia. A figura de "suave rosto inclinado no vão do tempo" (versos 18-19) reitera a ambivalência: o perfil humano formado pelo campo, destituído de qualquer traço individualizante, inclina-se para o lugar mitopoético do tempo elidido, em um processo que o desloca rumo a um espaço imaginado; todavia, o chinês é situado próximo, mas ainda fora desse novo mundo. Portanto, à utopia prefigurada pelo poema somase a sua impossibilidade imediata de concretização, reiterando um posicionamento radicalmente desconfiado que, por recusar qualquer triunfalismo, projeta a vida plena para outro momento, ainda que haja certeza quanto à consecução futura do ideal. Como em "Cidade prevista", o "mundo sem igreja nem quartéis" viria "um dia, dentro em mil anos...". (ANDRADE, 2012b, p. 126)

Em suma, a "ação" proposta por Drummond ao seu interlocutor (e a si) em "Campo, chinês e sono" aparece sem idealizações, como momento necessário de um processo que desembocaria na utopia cumprida e permitiria ao indivíduo o "tão somente ser, sem qualquer ordem ou cumprimento"; um "nada fazer boiando na água, fitando 
$\overline{7}$ Enquanto, em âmbito nacional, o PCB ensaiava o seu contraditório apoio a Vargas (que se consumaria em 1945), a invasão japonesa em 1937 levava à formação, na China, de uma frente ampla que congregava as forças nacionalistas, lideradas por ChiangKai-shek, e comunistas, dirigidas por Mao Tsé-Tung, líder que desenvolveu técnicas de mobilização de massa a fim de fortalecer seu apoio popular no campo (Cf. Johnathan Spence, Op. Cit., p. 422).

${ }^{8}$ Para outra leitura que compara Drummond e Cabral, ver o ensaio de Anderson Gonçalves, "Vastidão sem norte". pacificamente o céu", que, na sociedade emancipada, ocuparia o lugar do processo produtivo (ADORNO, 2008, p. 154) - a inação e o apagamento subjetivos que Cabral buscava alcançar de forma imediata, enfim.

A projeção desse futuro, bem como o invólucro delicado pelo qual Drummond apresenta a figura de um chinês a meio caminho da utopia, "abraçando-o sem reduzi-lo" (para falar com outro poema fundamental e hermético do livro, "Fragilidade") (ANDRADE, 2012b, p. 47), afinam-se com um momento histórico que, se por um lado requeria o alinhamento à esquerda como forma de combater o nazifascismo e a ditadura local, por outro não implicava anuência plena quanto aos caminhos traçados pelos PCs, marcados pela composição com as forças burguesas "progressistas" tanto no Brasil quanto na China7. De maneira que, n' $A$ Rosa do povo e no poema analisado, o engajamento eivado de dúvidas e de desconfianças, galvanizado pelo autoexame e pelo questionamento quanto ao alcance da poesia, acaba por revelar, como definiu Iumna Simon, "a coragem de Drummond de assumir temores e aflições, fraquezas e irresoluções, para assumir insubordinadamente uma moral literária". (SIMON, 2015, p. 190)

Essa moral literária passa necessariamente pela oposição à autonomia poética e ao absoluto da linguagem, expressa, em "Campo, chinês e sono", na presença de uma subjetividade atuante, na referência explícita ao "tu" e na ênfase de sua relação com o mundo. O chamado em suspenso, entretanto, revela igualmente a desconfiança quanto à capacidade da poesia de falar diretamente aos homens e de subverter a ordem social, embora tal subversão seja a causa mesma de seu engajamento. De todo modo, somente a partir da anulação da individualidade, cujo requisito prévio, paradoxalmente, seria a percepção do homem como um "animal político", é que o novo mundo, até então apenas intuído, poderia se constituir.

A ironia aguda de Drummond consiste, neste caso, na construção de um poema hermético e aparentemente intransitivo, que, no entanto, põe em cena justamente uma subjetividade situada e a necessidade da comunicação. Tal combinação sugere que o hermetismo de algumas das composições de $A$ rosa do povo não corresponde à ausência das mediações históricas e não prescinde de uma abertura, ainda que cifrada, para a vida social, configurando um modo específico de comunicação e de formalização de impasses reais que nada tem a ver com absenteísmo ${ }^{8}$. 
Na calculada arquitetura d' A rosa, "Campo, chinês e sono" vem precedido de "Vida menor", no qual o eu lírico procura o tempo "domado", e é imediatamente sucedido por "Episódio", outro poema em geral associado ao "fechamento do discurso" (Cf. SIMON, 1984, p. 170 e ss.). Nele, o sujeito poético depara com um boi que, tal como a flor que brota do asfalto, é "alheio à polícia" e "anterior ao tráfego". O eu-lírico pede ao boi, então, que o leve para um "reino outro":

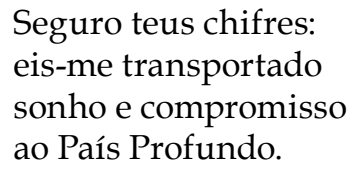

(ANDRADE, 2012b, p. 51)

Curiosamente, não se trata, aqui, mais do sono do chinês, mas do sonho - um estágio que, de acordo com a armação rigorosa dos poemas do livro, surge como decorrência do sono, tal como Cabral havia teorizado. No entanto, ao Drummond de "Episódio" não basta o sonho desvinculado do compromisso, mas a conjugação de ambos. Por isso o eu-lírico é conduzido ao "País Profundo", que tanto pode ser o país sem o véu da ideologia quanto, revolvendo as raízes familiares ao poeta, uma alusão às Minas Gerais, "palavra abissal" que é "dentro e fundo", como ele dirá, mais tarde, $\mathrm{n}^{\prime}$ As impurezas do branco (ANDRADE, 2012a, p. 112). Trata-se, de todo modo, de um movimento de fuga paradoxal, que reitera o compromisso de Drummond com as questões de seu tempo, pois um ser do mundo natural transporta o eu-lírico para o núcleo de mazelas nacionais (e pessoais) das quais o poeta pretendia, ainda que por um instante, se desvencilhar.

\section{REFERÊNCIAS}

ADORNO, T, Minima moralia: reflexões a partir da vida lesada. Trad. Gabriel Cohn. Rio de Janeiro: Azougue Editorial, 2008.

ANDRADE, C. D. de. Passeios na ilha: divagações sobre a vida literária e outras matérias. Rio de Janeiro: José Olympio, 1975. O observador no escritório. Rio de Janeiro: Record,

1985. 
ANDRADE, C. D. de. Confissões de Minas. São Paulo: Cosac \& Naify. 2011

As impurezas do branco. São Paulo: Companhia das Letras, 2012a.

. A rosa do povo. São Paulo: Companhia das Letras, 2012b.

. Sentimento do mundo. São Paulo: Companhia das Letras, 2012c.

BARBOSA, J. B. A imitação da forma: uma leitura de João Cabral de Melo Neto. São Paulo: Duas Cidades, 1975.

BAUDELAIRE. C. As flores do mal. Trad. Ivan Junqueira. Rio de Janeiro: Nova Fronteira, 1985.

CAMILO, V. Figurações espaciais e mapeamentos na lírica social de Drummond. Redobra n. 13, ano 5, p. 57-58, 2014.

CAMPOS, H. de. O geômetra engajado. In: Metalinguagem e outras metas. São Paulo: Perspectiva, 2006.

CANDIDO, A. Inquietudes na poesia de Drummond. In: Vários escritos. São Paulo: Duas Cidades, 1970.

Poesia ao norte. In: Textos de intervenção. Organização

Vinícius Dantas. São Paulo: Duas Cidades: Editora 34, 2002

ESFERA: revista de letras, artes e ciências. Rio de Janeiro, ano 3, n. 9, mar. 1944.

GULLAR, Ferreira. Autobiografia poética e outros textos. São Paulo: Autêntica, 2015.

HOUAISS, A. Dicionário Houaiss da Língua Portuguesa. Rio de Janeiro: Objetiva, 2001.

FREIXEIRO, F. Da razão à emoção II. Rio de Janeiro: Tempo Brasileiro, 1971. 
GLEDSON, J. Sono, poesia e o livro falso de João Cabral de Melo Neto. In: Influências impasses: Drummond e alguns contemporâneos. São Paulo: Companhia das Letras, 2003.

MELO NETO, J. C. de. Considerações sobre o poeta dormindo. In: Obra completa. Rio de Janeiro: Nova Aguilar, 1994.

MENDES, M. As metamorfoses. São Paulo: Cosac \& Naify, 2015.

MERLEAU PONTY, M. A dúvida de Cézanne. In: $O$ olho $e$ o espírito: seguido de A linguagem indireta e A dúvida de Cézanne. São Paulo: Cosac Naify, 2004.

PAULINO, A. M. Um pouco sobre 'Campo, chinês e sono'. Revista do Instituto de Estudos Brasileiros, 29, p. 7-13, 1988.

PEIXOTO, M. Poesia com coisas: uma leitura de João Cabral de Melo Neto. São Paulo: Perspectiva, 1983.

SIMON, I. M. Drummond: uma poética do risco. São Paulo: Ática, 1984.

O mundo em chamas e o país inconcluso. Revista Novos Estudos Cebrap, n. 103, p.190, 2015.

SPENCE, J. Em busca da China moderna: quatro séculos de história. Trad. Tomás Rosa Bueno e Pedro Maia Soares. São Paulo: Companhia das Letras, 1995.

SUSSEKIND, F. Correspondência de Cabral com Bandeira e Drummond. Rio de Janeiro: Nova Fronteira: Casa de Rui Barbosa, 2001. 


\section{Abstract \\ The Sleepless Poet}

This article is aimed at understanding, through the analysis of the poem "Campo, chinês e sono", from A rosa do povo (1945), how Carlos Drummond de Andrade answers, critically and creatively, to João Cabral de Melo Neto's the compositions in the book Pedra do sono, guided by the attempt to unsubjectify and forget the self. To that end, the text uses the correspondence between the authors and theoretical formulations of Cabral himself. The poetic and political answer given by Drummond in "Campo, chinês e sono", in which one may foresee, in a utopian fashion, the building of a fair and emancipated society, allow us to also rethink the supposed intransitivity of some of the hermetic poems in A rosa do povo.

Keywords: Carlos Drummond de Andrade; João Cabral de Melo Neto; lyricism and society; modern lyricism; Communism. 